\title{
Article \\ Reduction of Potential-Induced-Degradation of p-Type PERC Solar Cell Modules by an Ion-Diffusion Barrier Layer Underneath the Front Glass
}

\author{
Eunjin Jang ${ }^{1}\left(\mathbb{D}\right.$, Kyoung-suk Oh ${ }^{2,3}$ and Sangwoo Ryu ${ }^{1, *(D)}$ \\ 1 Department of Advanced Materials Engineering, Kyonggi University, Suwon 16227, Korea; \\ eunjin23@kyonggi.ac.kr \\ 2 New \& Renewable Energy Research Center, Korea Electronics Technology Institute, Seongnam 13509, Korea; \\ ks.oh@hyundai-es.co.kr \\ 3 PV Module Development Team, Hyundai Energy Solution, Chungcheongbuk-do 27711, Korea \\ * Correspondence: sryu@kyonggi.ac.kr; Tel.: +82-31-249-9761
}

check for updates

Citation: Jang, E.; Oh, K.-s.; Ryu, S Reduction of Potential-InducedDegradation of p-Type PERC Solar Cell Modules by an Ion-Diffusion Barrier Layer Underneath the Front Glass. Processes 2022, 10, 334 https://doi.org/10.3390/pr10020334 Academic Editor: Sung-Churl Choi

Received: 14 January 2022 Accepted: 7 February 2022 Published: 10 February 2022

Publisher's Note: MDPI stays neutral with regard to jurisdictional claims in published maps and institutional affiliations.

Copyright: (C) 2022 by the authors. Licensee MDPI, Basel, Switzerland. This article is an open access article distributed under the terms and conditions of the Creative Commons Attribution (CC BY) license (https:// creativecommons.org/licenses/by/ $4.0 /)$.

\begin{abstract}
With the maturation of silicon-based technologies, silicon solar cells have achieved a high conversion efficiency that approaches the theoretical limit. Currently, great efforts are being made to enhance the reliability of silicon solar cells. When the silicon solar cells are made into modules, potential-induced-degradation (PID) occurs during operation because of the high voltage applied between the frame and the cells, which reduces the efficiency and output power. The diffusion of $\mathrm{Na}^{+}$ ions from the front glass and the increased leakage current along the migration path are the major causes of PID. In this work, atomic layer deposition (ALD)-grown amorphous thin $\mathrm{Al}_{2} \mathrm{O}_{3}$ layers are introduced underneath the front glass to prevent the diffusion of $\mathrm{Na}^{+}$ions and the resulting PID. Accelerated PID tests showed that an ALD-grown $\mathrm{Al}_{2} \mathrm{O}_{3}$ layer of $30 \mathrm{~nm}$ could effectively suppress PID seriously affecting the conversion efficiency or light transmittance. The introduction of an ion-diffusion barrier underneath the front glass is expected to contribute to securing the long-term reliability of silicon-based electricity generation, together with the introduction of barrier layers inside the solar cells.
\end{abstract}

Keywords: potential-induced degradation; PERC solar cell module; ion-diffusion barrier; $\mathrm{Al}_{2} \mathrm{O}_{3}$

\section{Introduction}

As the demand for energy continues to increase worldwide, interest in eco-friendly renewable energy has accelerated because of the increasingly serious environmental pollution and global warming, which is recognized as the main culprit of climate change. Solar energy conversion devices, especially photovoltaic cells, have been regarded as most promising among the various types of renewable energy because of their unlimited reserves and high energy conversion efficiency [1,2]. Among the photovoltaic devices, crystalline silicon solar cells have developed most rapidly, because of their high conversion efficiency and a mature silicon-based industry; as a result, they account for more than $80 \%$ of the global solar cell market [3-6]. According to the Best Research-Cell Efficiency chart reported by the National Renewable Energy Laboratory, the highest cell efficiency for a single-crystalline silicon solar cell is $26.1 \%$, achieved by the Institute for Solar Energy Research, Germany [7].

Most solar cell modules provided in the market guarantee operation for longer than 25 years. As the conversion efficiency approaches the theoretical limit of $29 \%$, the interest is shifting from efficiency to long-term stability.

When silicon solar cell modules are connected in series to produce a high voltage of $600-1000 \mathrm{~V}$, the same high voltage is applied between the grounded module frame and the solar cell, which causes a large leakage current and loss of power output during the production of electricity. This is referred to as potential-induced-degradation (PID), which 
deteriorates the photovoltaic performance of crystalline silicon solar cell modules over a long period of time [8-12].

PID is known to occur as a result of the diffusion of $\mathrm{Na}^{+}$ions present in the soda-lime front glass that is generally used for silicon solar cell modules and contains $12 \% \mathrm{Na}_{2} \mathrm{O}$. When a high voltage is applied, $\mathrm{Na}^{+}$ions inside the front glass diffuse into the cells across the encapsulant and anti-reflection coatings. The diffused $\mathrm{Na}^{+}$ions accumulate at the interface between the anti-reflection coatings and the cells or at the stacking faults inside the silicon, which forms a conduction path, leading to a large leakage current [13-17], which gradually degrades the conversion efficiency and maximum power output of the modules.

The PID can be reduced by adjusting the refractive index of the anti-reflection coatings formed on top of the cells. As the refractive index of silicon nitride $\left(\mathrm{SiN}_{\mathrm{x}}\right)$, which is typically used for the anti-reflection coating of silicon solar cells, increases, the conductivity also increases, resulting in a reduction in the migration of positively charged ions to $\mathrm{SiN}_{\mathrm{x}}$. This effectively enhances the resistance to PID. However, if the refractive index becomes higher than 2.14 , light with a short wavelength cannot be absorbed by silicon, causing a decrease in the cell efficiency as a result of the reduction in the photocurrent [16-18].

An alternative way to prevent PID is to insert a layer that can block the penetration of ions from the glass $[19,20]$. This layer can be located between the front glass and the front encapsulant or between the anti-reflection coating and the cell. These blocking layers are known to effectively suppress the diffusion of $\mathrm{Na}^{+}$ions inside the glass and the shunting path and consequently reduce PID. Possible candidates for this blocking layer include $\mathrm{Al}_{2} \mathrm{O}_{3}, \mathrm{TiO}_{2}$, and $\mathrm{SiO}_{2}$ [21-23]. Previous work done by Jung et al. shows that an ultrathin layer of $\mathrm{SiO}_{x}$ formed between the cell and the anti-reflection coating effectively reduces PID [24].

Herein, we explored the effect of $\mathrm{Al}_{2} \mathrm{O}_{3}$ thin layers, which are known to have high light transmittance with outstanding barrier performance against ion diffusion, on the reduction of PID in silicon solar cell modules. As the thickness of $\mathrm{Al}_{2} \mathrm{O}_{3}$ increased, the PID was remarkably reduced, and a $30 \mathrm{~nm}$ layer of $\mathrm{Al}_{2} \mathrm{O}_{3}$ could suppress PID effectively.

\section{Materials and Methods}

Ions can diffuse through the grain boundaries in crystalline $\mathrm{Al}_{2} \mathrm{O}_{3}$ layers, and an amorphous phase of $\mathrm{Al}_{2} \mathrm{O}_{3}$ is required for suitable performance as a diffusion barrier. For this purpose, thermal atomic layer deposition (ALD) was utilized for the growth of the $\mathrm{Al}_{2} \mathrm{O}_{3}$ ion diffusion barrier layers. Soda-lime glass and quartz were cut to a size of $5 \mathrm{~cm} \times 5 \mathrm{~cm}$. These substrates were first ultrasonically cleaned with acetone, methanol, and isopropyl alcohol sequentially for $15 \mathrm{~min}$ each and finally rinsed with deionized water. The cleaned glass substrates were then dried in a thermal ALD chamber at $150{ }^{\circ} \mathrm{C}$ for $30 \mathrm{~min}$. Thermal ALD of $\mathrm{Al}_{2} \mathrm{O}_{3}$ was performed at the same temperature with trimethylaluminum (TMA, $\left.\mathrm{Al}\left(\mathrm{CH}_{3}\right)_{3}\right)$ and $\mathrm{H}_{2} \mathrm{O}$ as the precursor and reactant, respectively. During each cycle, the substrate was exposed to the precursor for $0.2 \mathrm{~s}$, followed by purging with $80 \mathrm{sccm}$ of Ar for $20 \mathrm{~s}$.

Structural characterization was performed using X-ray diffraction (Empyrean, Malvern Panalytical, Malvern, UK) and scanning electron microscopy (JSM-7610F Plus, Jeol, Tokyo, Japan). The light transmittance was measured using UV-vis spectroscopy (Optizen POP, K $\mathrm{LAB}$, Daejeon, Korea) for 10 to $30 \mathrm{~nm} \mathrm{Al}_{2} \mathrm{O}_{3}$ films deposited on quartz substrates.

To characterize the PID, an acceleration test was performed using IEC62804-1, an internationally recognized standard-based solar cell test device [25]. For silicon solar cells, passivated emitter and rear contact (PERC) cells, which represent the largest portion of the market, were used. As shown in Figure 1, p-type PERC solar cells, encapsulants, and $\mathrm{Al}_{2} \mathrm{O}_{3}$-grown sola-lime glass were placed on an aluminum chuck heated to $60{ }^{\circ} \mathrm{C}$ on a hot plate [26]. Then, a 2-kg weight was loaded on top of the glass and $+1000 \mathrm{~V}$ was applied to the bottom aluminum chuck for $96 \mathrm{~h}$. Light I-V curves and electroluminescence (EL) images were obtained to evaluate the effect of the blocking layers on PID. To ensure testing uniformity, four module-like layer stacks underwent an accelerated test at the same time. 
Note that PERC solar cells without oxidation layers inserted between the anti-reflection coating and the cell were examined because these oxidation layers inside the cells are known to prevent PID as well.
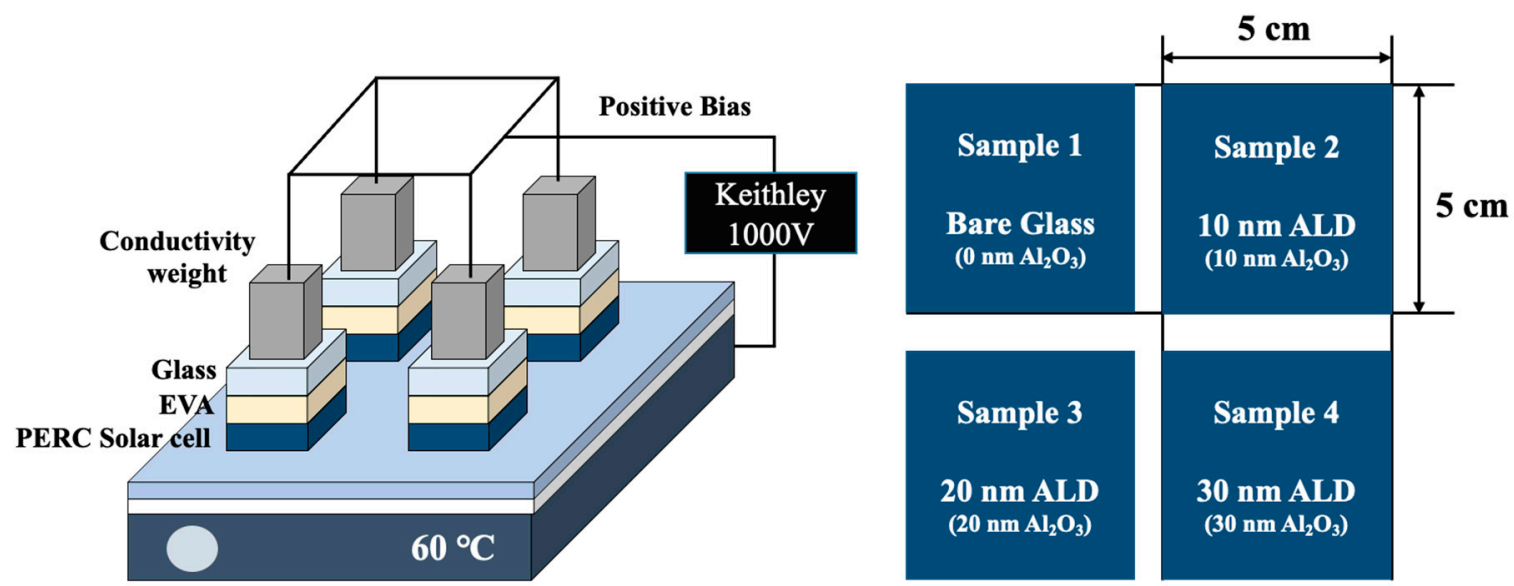

Figure 1. Schematic of the accelerated PID test. A $2 \mathrm{~kg}$ weight made of aluminum was used. Four module-like stack samples were tested at the same time. After $96 \mathrm{~h}$, each stack was disassembled, and I-V measurements were performed.

\section{Results and Discussion}

3.1. Characterization of the ALD-Grown $\mathrm{Al}_{2} \mathrm{O}_{3}$ for Si-Solar Cell Usage

3.1.1. Uniform Growth of $\mathrm{Al}_{2} \mathrm{O}_{3}$ with Amorphous Structure

Figure 2 shows the SEM plan view and cross-section view images of the ALD-grown $\mathrm{Al}_{2} \mathrm{O}_{3}$ thin films on $\mathrm{Si}$ wafer (a) and glass (b), (c). For both $\mathrm{Al}_{2} \mathrm{O}_{3}$ films, the calibrated growth rate was $1.3 \AA$ /cycle. SEM plan view images of the $\mathrm{Al}_{2} \mathrm{O}_{3}$ films, as shown in Figure 2a,b, allow reasonable doubt regarding the polycrystalline microstructure. However, all the ALD-grown $\mathrm{Al}_{2} \mathrm{O}_{3}$ thin films investigated in this work exhibited an amorphous structure, which is confirmed by the absence of a pronounced XRD peak (not shown), as is generally expected for films grown by ALD.
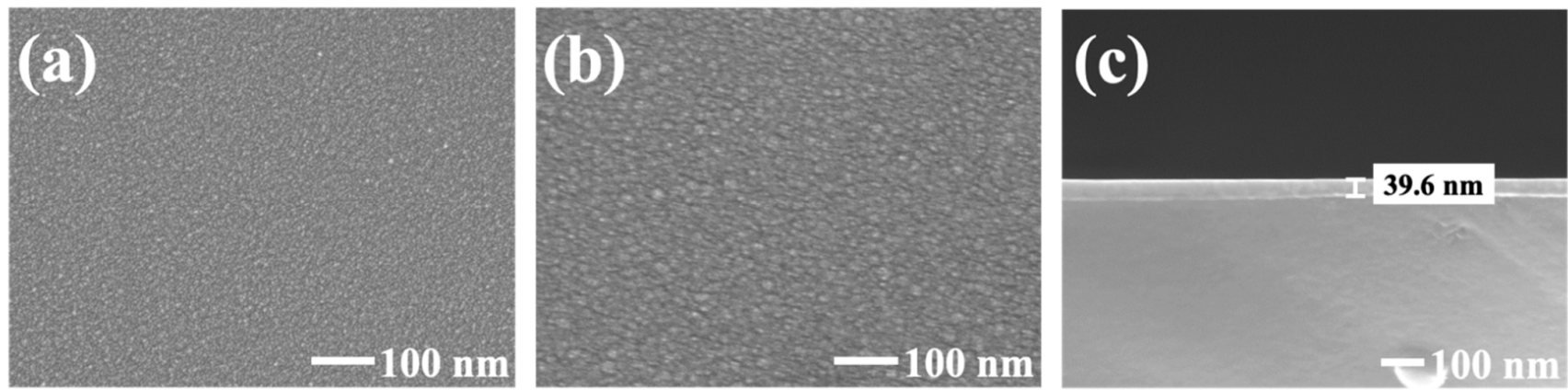

Figure 2. SEM plan view images of the ALD-grown $\mathrm{Al}_{2} \mathrm{O}_{3}$ thin films on (a) single crystalline $\mathrm{Si}$ wafer, (b) glass. (c) SEM cross-section view image of the ALD-grown $\mathrm{Al}_{2} \mathrm{O}_{3}$ thin films on a glass.

\subsubsection{Optical Transmittance and Passivation Properties of $\mathrm{Al}_{2} \mathrm{O}_{3}$ Thin Films}

Prior to the accelerated PID test, the light transmittance of $\mathrm{Al}_{2} \mathrm{O}_{3}$-coated quartz substrates with various $\mathrm{Al}_{2} \mathrm{O}_{3}$ thicknesses was characterized, as shown in Figure $3 \mathrm{a}, \mathrm{b}$. Note that light transmittance through the glass and light absorption by silicon decreased with a thick $\mathrm{Al}_{2} \mathrm{O}_{3}$ layer. As presented in Figure 3a, the light transmittance in the wavelength range of 200-300 nm was slightly reduced with increasing thickness of $\mathrm{Al}_{2} \mathrm{O}_{3}$. However, the average transmittance for the 200-1000 nm range was greater than $94 \%$ and independent 
of the $\mathrm{Al}_{2} \mathrm{O}_{3}$ thickness, although the transmittance for $30 \mathrm{~nm}$ was slightly smaller than the others.

(a)

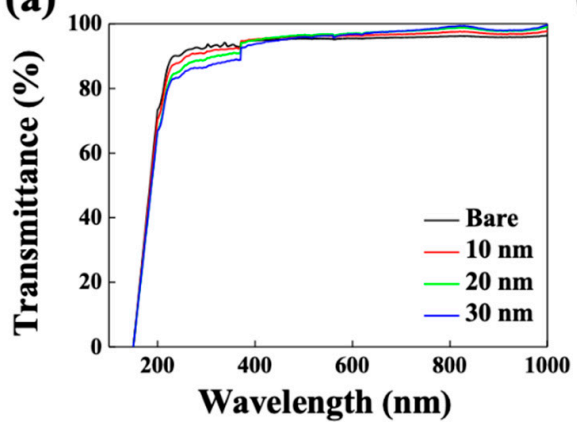

(b)

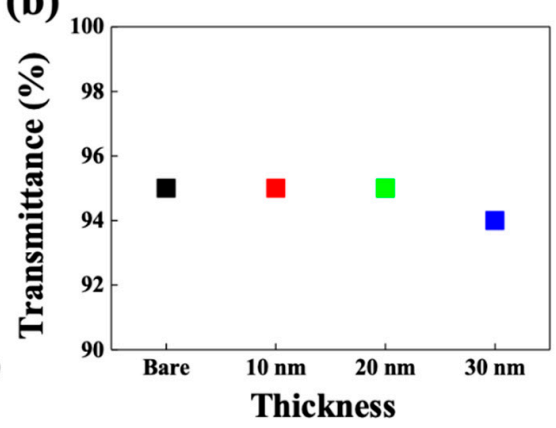

(c)

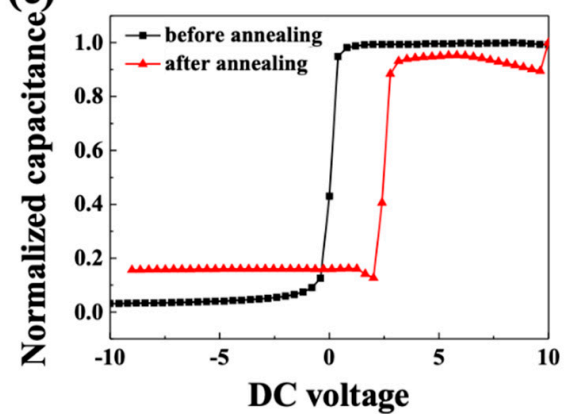

Figure 3. (a) Light transmittance for 200 to $1000 \mathrm{~nm}$ range of $\mathrm{ALD}$-grown $\mathrm{Al}_{2} \mathrm{O}_{3}$ thin films with various thicknesses. (b) Average light transmittance with respect to the thickness of the $\mathrm{Al}_{2} \mathrm{O}_{3}$ layer. (c) Capacitance-voltage profile of a p-type single-crystalline silicon wafer passivated by the ALD-grown $10 \mathrm{~nm} \mathrm{Al}_{2} \mathrm{O}_{3}$ thin layers.

To further confirm the validity of the ALD process used in this work for $\mathrm{Al}_{2} \mathrm{O}_{3}$ thin film growth, we examined the surface passivation properties using capacitance-voltage measurements. For $10 \mathrm{~nm}$-thick $\mathrm{Al}_{2} \mathrm{O}_{3}$ films grown on p-type single-crystalline $\mathrm{Si}$ wafers, the capacitance-voltage profile shifted to a positive bias after annealing, as shown in Figure 3I, which is indicative of negatively charged $\mathrm{Al}_{2} \mathrm{O}_{3}$ thin films with the appropriate passivation properties of well-grown $\mathrm{Al}_{2} \mathrm{O}_{3}$ thin films.

\subsection{Accelerated PID Test with Light I-V and Electroluminescent Measurement}

The results of the accelerated PID tests are shown in Figure 4. As mentioned in the Materials and Methods section, the current and voltage with and without light were measured before and after loading a $2 \mathrm{~kg}$ weight for $96 \mathrm{~h}$. Note that the reference sample is the initial module before the accelerated PID test. The rest of the samples correspond to the measurement results after the accelerated PID test with respect to the designated $\mathrm{Al}_{2} \mathrm{O}_{3}$ layer thickness. Before the PID test, all the modules showed similar I-V characteristics; therefore, only the module without the $\mathrm{Al}_{2} \mathrm{O}_{3}$ layer was used as the reference.

As shown in Figure $4 \mathrm{a}$, the $\mathrm{Al}_{2} \mathrm{O}_{3}$ layer deposited underneath the front glass can effectively prevent PID. Without the $\mathrm{Al}_{2} \mathrm{O}_{3}$ diffusion barrier, $\mathrm{V}_{\mathrm{oc}}$ was remarkably reduced, from $0.658 \mathrm{~V}$ to $0.572 \mathrm{~V}$. However, a $10 \mathrm{~nm}$-thick layer of $\mathrm{Al}_{2} \mathrm{O}_{3}$ recovers $\mathrm{V}_{\mathrm{oc}}$ to that of the reference module. $\mathrm{J}_{\mathrm{sc}}$ does not change significantly, which can be inferred from the similar light absorption properties presented in Figure 3. All the modules exhibited similar series resistance, which can be obtained from the slope that crosses the voltage axis, regardless of the presence of the $\mathrm{Al}_{2} \mathrm{O}_{3}$ diffusion barrier layer. However, slopes that cross the current axis showed different behavior; the module without the $\mathrm{Al}_{2} \mathrm{O}_{3}$ layer showed a quite stiff slope, whereas the slopes of the modules with the $\mathrm{Al}_{2} \mathrm{O}_{3}$ layer recovered close to that of the reference. This is predictable because the leakage current that causes PID is related to the shunt resistance and not to the series resistance.

Although the $\mathrm{V}_{\mathrm{oc}}$ and $\mathrm{J}_{\mathrm{sc}}$ of the cells with $\mathrm{Al}_{2} \mathrm{O}_{3}$ layers were almost the same, regardless of the thickness of $\mathrm{Al}_{2} \mathrm{O}_{3}$, the change in the fill factor and the solar conversion efficiency of each module were remarkably reduced in cells with an $\mathrm{Al}_{2} \mathrm{O}_{3}$ layer, as shown in Figure $4 \mathrm{~b}$. The fill factor decreased from $75.3 \%$ to $72.4 \%$ without the $\mathrm{Al}_{2} \mathrm{O}_{3}$ layer, while it recovered to its initial value when employing an $\mathrm{Al}_{2} \mathrm{O}_{3}$ layer of only $10 \mathrm{~nm}$. Without the $\mathrm{Al}_{2} \mathrm{O}_{3}$ layer, the conversion efficiency deteriorated significantly; it dropped by approximately $18.8 \%$ after the PID test. However, as the thickness of $\mathrm{Al}_{2} \mathrm{O}_{3}$ increased, the efficiency drop tended to decrease, even though there was some fluctuation. Even with only $10 \mathrm{~nm} \mathrm{of} \mathrm{Al}_{2} \mathrm{O}_{3}$, the efficiency after the PID test for $96 \mathrm{~h}$ was 19.92\%, which indicates that the efficiency 
decreased by approximately $2.54 \%$. When the thickness of $\mathrm{Al}_{2} \mathrm{O}_{3}$ was $30 \mathrm{~nm}$, the efficiency loss was only $0.98 \%$ after the PID test.
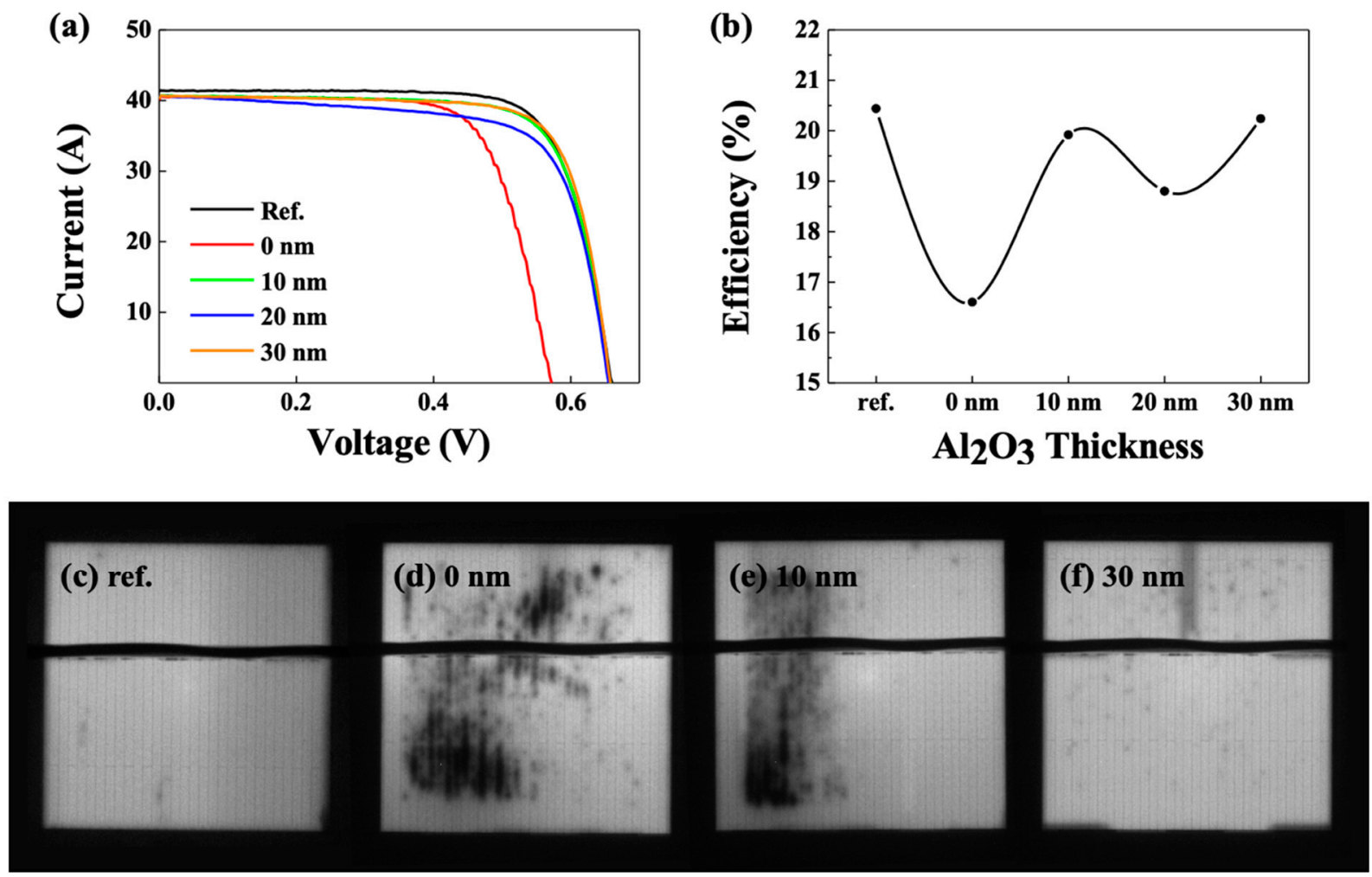

Figure 4. Characterization results of PERC cells after the accelerated PID test. (a) Light I-V, (b) efficiency changes, electroluminescent images obtained after the PID test; (c) ref-before the PID test, (d) without the $\mathrm{Al}_{2} \mathrm{O}_{3}$ layer, (e) $10 \mathrm{~nm} \mathrm{Al}_{2} \mathrm{O}_{3}$, and (f) $30 \mathrm{~nm} \mathrm{Al}_{2} \mathrm{O}_{3}$.

PID causes the formation of defects inside the cell, which can be analyzed by EL. As presented in Figure 4c-f, lots of defects were generated, possibly due to the diffusion of $\mathrm{Na}^{+}$ions, after the PID test when no $\mathrm{Al}_{2} \mathrm{O}_{3}$ layer was inserted. Although $10 \mathrm{~nm}$-thick $\mathrm{Al}_{2} \mathrm{O}_{3}$ demonstrated a quite reduced PID as shown in light I-V measurement results, EL images of $10 \mathrm{~nm}$ indicated that there were still non-negligible number of defects. It could be confirmed that the defects caused by the diffusion of $\mathrm{Na}^{+}$ions disappeared only when the thickness was $30 \mathrm{~nm}$.

From the light I-V measurement and EL results, it can be concluded that the optimum thickness of $\mathrm{Al}_{2} \mathrm{O}_{3}$, the diffusion barrier of $\mathrm{Na}^{+}$ions from the front glass, is $30 \mathrm{~nm}$. All the changes of the photovoltaic parameters with various $\mathrm{Al}_{2} \mathrm{O}_{3}$ thicknesses after the accelerated PID test were summarized in Table 1.

Table 1. Photovoltaic parameters with various $\mathrm{Al}_{2} \mathrm{O}_{3}$ thicknesses after the accelerated PID test. The changes with respect to the values of reference sample are shown together in the parentheses.

\begin{tabular}{|c|c|c|c|c|}
\hline Sample & $\begin{array}{c}\mathrm{V}_{\mathrm{OC}} \\
(\mathrm{V})\end{array}$ & $\begin{array}{c}\mathrm{JSC} \\
\left(\mathrm{mA} / \mathrm{cm}^{2}\right)\end{array}$ & $\begin{array}{l}\text { FF } \\
(\%)\end{array}$ & $\begin{array}{c}\text { Efficiency } \\
(\%)\end{array}$ \\
\hline Reference & 0.658 & 41.24 & 75.3 & 20.44 \\
\hline $0 \mathrm{~nm} \mathrm{Al}{ }_{2} \mathrm{O}_{3}$ & $\begin{array}{c}0.572 \\
(-13.07 \%)\end{array}$ & $\begin{array}{c}40.08 \\
(-2.81 \%)\end{array}$ & $\begin{array}{c}72.4 \\
(-3.85 \%)\end{array}$ & $\begin{array}{c}16.6 \\
(-18.79 \%)\end{array}$ \\
\hline $10 \mathrm{~nm} \mathrm{Al}{ }_{2} \mathrm{O}_{3}$ & $\begin{array}{c}0.658 \\
(0 \%)\end{array}$ & $\begin{array}{c}40.32 \\
(-2.23 \%)\end{array}$ & $\begin{array}{c}75.1 \\
(-0.27 \%)\end{array}$ & $\begin{array}{c}19.92 \\
(-2.54 \%)\end{array}$ \\
\hline $20 \mathrm{~nm} \mathrm{Al}{ }_{2} \mathrm{O}_{3}$ & $\begin{array}{c}0.655 \\
(-0.46 \%)\end{array}$ & $\begin{array}{c}40.48 \\
(-1.84 \%)\end{array}$ & $\begin{array}{c}70.9 \\
(-5.84 \%)\end{array}$ & $\begin{array}{c}18.8 \\
(-8.02 \%)\end{array}$ \\
\hline $30 \mathrm{~nm} \mathrm{Al}{ }_{2} \mathrm{O}_{3}$ & $\begin{array}{l}0.658 \\
(0 \%)\end{array}$ & $\begin{array}{c}40.28 \\
(-2.32 \%)\end{array}$ & $\begin{array}{c}76.4 \\
(1.46 \%)\end{array}$ & $\begin{array}{c}20.24 \\
(-0.98 \%)\end{array}$ \\
\hline
\end{tabular}


According to V. Naumann et al., an accumulation of alkali metals should be found at the interface of the front side coatings of the solar cell, which can be demonstrated by lock-in thermography (LIT), and time-of-flight secondary ion mass spectroscopy (ToF-SIMS), when PID occurs [27]. Further investigation using these analysis techniques would manifest the correlation between the occurrence of PID and the diffusion of $\mathrm{Na}^{+}$ions.

\section{Conclusions}

The improvement in solar cell efficiency has received much recent attention, and intensive research to achieve higher efficiency has been conducted. However, with the widespread use of solar cells, long-term reliability has become another important aspect. PID is regarded as a major source of deterioration that occurs during operation when silicon-based solar cells are made into modules. The diffusion of $\mathrm{Na}^{+}$ions into the cells and the resulting increase in leakage current are one of the main causes of PID. When ALD-grown amorphous $\mathrm{Al}_{2} \mathrm{O}_{3}$ thin layers of $30 \mathrm{~nm}$ are introduced underneath the front glass of the module, PID is effectively prevented without a serious decrease in the $\mathrm{V}_{\mathrm{oc}}, \mathrm{J}_{\mathrm{Sc}}$, or solar conversion efficiency. This method is expected to have a greater effect when this $\mathrm{Na}^{+}$ion-diffusion barrier is combined with the insertion of another barrier layer between the anti-reflection coatings and solar cells.

Author Contributions: Conceptualization, E.J., K.-s.O. and S.R.; methodology, E.J.; experimental design, sample fabrication, data curation, E.J. and K.-s.O.; writing, E.J.; review and editing, S.R.; supervision, project administration, funding acquisition, S.R. All authors have read and agreed to the published version of the manuscript.

Funding: This work was supported by the Korea Institute of Energy Technology Evaluation and Planning (KETEP) and the Ministry of Trade, Industry \& Energy (MOTIE) of the Republic of Korea (No. 20183010014320). This work was also supported by Korea Institute for Advancement of Technology (KIAT) grant funded by the Korea Government (MOTIE) (P0017012, Human Resource Development Program for Industrial Innovation). Also, this work was supported by Kyonggi University's Graduate Research Assistantship 2020.

Data Availability Statement: Not applicable.

Acknowledgments: We would like to thank Soo Min Kim at the Gumi Electronics \& Information Technology Research Institute regarding the formation of module-like layer structures and the accelerated PID test.

Conflicts of Interest: The authors declare no conflict of interest.

\section{References}

1. Saga, T. Advances in crystalline silicon solar cell technology for industrial mass production. NPG Asia Mater. 2010, 2, 96-102. [CrossRef]

2. Tsoutsos, T.; Frantzeskaki, N.; Gekas, V. Environmental impacts from the solar energy technologies. Energy Policy 2005, 33, 289-296. [CrossRef]

3. Gul, M.; Kotak, Y.; Muneer, T. Review on recent trend of solar photovoltaic technology. Energy Explor. Exploit. 2016, 34, 485-526. [CrossRef]

4. Battaglia, C.; Cuevas, A.; Wolf, S.D. High-efficiency crystalline silicon solar cells: Status and perspectives. Energy Environ. Sci. 2016, 9, 1552-1576. [CrossRef]

5. Wilson, G.M.; Al-Jassim, M.; Metzger, W.K.; Glunz, S.W.; Verlinden, P.; Xiong, G.; Mansfield, L.M.; Stanbery, B.J.; Zhu, K.; Yan, Y.; et al. The 2020 photovoltaic technologies roadmap. J. Phys. D Appl. Phys. 2020, 53, 493001. [CrossRef]

6. Chaar, L.E.; Iamont, L.A.; Zein, N.E. Review of photovoltaic technologies. Renew. Sust. Energy Rev. 2011, 15, 2165-2175. [CrossRef]

7. Yoshikawa, K.; Kawasaki, H.; Yoshida, W.; Irie, T.; Konishi, K.; Nakano, K.; Uto, T.; Adachi, D.; Kanematsu, M.; Uzu, H.; et al. Silicon heterojunction solar cell with interdigitated back contacts for a photoconversion efficiency over 26\%. Nat. Energy 2017, 2, 17032. [CrossRef]

8. Nagel, H.; Metz, A.; Wangemann, K. Crystalline Si solar cells and modules featuring excellent stability against potential-induced degradation. In Proceedings of the 26th European Photovoltaic Solar Energy Conference and Exhibition, Hamburg, Germany, 5-9 September 2011.

9. Harvey, S.P.; Aguiar, J.A.; Hacke, P.; Guthrey, H.; Johnston, S.; Al-Jassim, M. Sodium Accumulation at Potential-Induced Degradation Shunted Areas in Polycrystalline Silicon Modules. IEEE J. Photovoltaics 2016, 6, 1440-1445. [CrossRef] 
10. Lausch, D.; Naumann, V.; Graff, A.; Hähnel, A.; Breitenstein, O.; Hagendorf, C.; Bagdahn, J. Sodium Outdiffusion from Stacking Faults as Root Cause for the Recovery Process of Potential-induced degradation (PID). Energy Procedia 2014, 55, 486-493. [CrossRef]

11. Jaeckel, B.; Cosic, M.; Arp, J. PID Effect of c-Si Modules: Study of Degradation and Recovery to More Closely Mimic Field Behavior. Isr. J. Chem. 2015, 55, 1091-1097. [CrossRef]

12. Bora, B.; Mondal, S.; Prasad, B.; Sastry, O.S.; Bangar, M.; Tripathi, A.K.; Banerjee, C. Accelerated stress testing of potential induced degradation susceptibility of PV modules under different climatic conditions. Sol. Energy 2021, 223, 158-167. [CrossRef]

13. Xiao, C.; Jiang, C.S.; Harvey, S.P.; Sulas, D.; Chen, X.; Liu, J.; Pan, J.; Moutinho, H.; Norman, A.; Hacke, P.; et al. Large-Area Material and junction Damage in c-Si solar Cells by Potential-Induced Degradation. Sol. RRL 2019, 3, 1800303. [CrossRef]

14. Naumann, V.; Brzuska, C.; Werner, M.; Großer, S.; Hagendorf, C. Investigations on the formation of stacking fault-like PID-shunts. Energy Procedia 2016, 92, 569-575. [CrossRef]

15. Luo, W.; Khoo, Y.S.; Hacke, P.; Naumann, V.; Lausch, D.; Harvey, S.P.; Singh, J.P.; Chai, J.; Wang, Y.; Aberle, A.G.; et al Potential-induced degradation in photovoltaic modules: A critical review. Energy Environ. Sci. 2017, 10, 43-68. [CrossRef]

16. Pingel, S.; Frank, O.; Winkler, M.; Daryan, S.; Geipel, T.; Hoehne, H.; Berghold, J. Potential Induced Degradation of solar cells and panels. In Proceedings of the 2010 35th IEEE Photovoltaic Specialists Conference, Honolulu, HI, USA, $20-25$ June 2010.

17. Naumann, V.; Lausch, D.; Hähnel, A.; Bauer, J.; Breitenstein, O.; Graff, A.; Werner, M.; Swatek, S.; Großer, S.; Bagdahn, J.; et al Explanation of potential-induced degradation of the shunting type by Na decoration of stacking faults in Si solar cells. Sol. Energy Mater. Sol. Cells 2014, 120, 383-389. [CrossRef]

18. Bae, S.H.; Oh, W.W.; Kim, S.M.; Kim, Y.D.; Park, S.G.; Kang, Y.M.; Lee, H.S.; Kim, D.W. Potential Induced Degradation (PID) of Crystalline Silicon Solar Modules. Korean J. Mater. Res. 2014, 24, 326-337. [CrossRef]

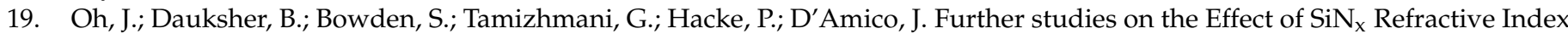
and Emitter Sheet Resistance on Potential-Induced Degradation. IEEE J. Photovoltaics 2017, 7, 437-443. [CrossRef]

20. Gou, X.; Li, X.; Zhou, S.; Wang, S.; Fan, W.; Huang, Q. PID Testing Method Suitable for Process Control of Solar Cells Mass Production. Int. J. Photoenergy 2015, 2015, 863248. [CrossRef]

21. Lu, L.; Shen, H.; Jiang, F.; Yang, C.; Lin, L. The enhanced conductivity of AZO thin films on soda lime glass with an ultrathin $\mathrm{Al}_{2} \mathrm{O}_{3}$ buffer layer. Phys. B Condens. Matter 2010, 405, 3320-3323. [CrossRef]

22. Hara, K.; Ichinose, H.; Murakami, T.N.; Masuda, A. Crystalline Si photovoltaic modules based on $\mathrm{TiO}_{2}$-coated cover glass against potential-induced degradation. RSC Adv. 2014, 4, 44291-44295. [CrossRef]

23. Kapur, J.; Stika, K.M.; Westphal, C.S.; Norwood, J.L.; Hamzavytehrany, B. Prevention of potential-induced degradation with thin ionomer film. IEEE J. Photovoltaics 2014, 5, 219-223. [CrossRef]

24. Jung, D.W.; Oh, K.S.; Jang, E.J.; Chan, S.I.; Ryu, S.W. Thickness Effect of $\mathrm{SiO}_{\mathrm{x}}$ Layer Inserted between Anti-Reflection Coating and p-n Junction on Potential-Induced Degradation (PID) of PERC Solar Cells. J. Microelectron. Packag. Soc. 2019, $26,75-80$.

25. Park, H.; Jeong, J.; Shin, E.; Kim, S.; Yi, J. A reliability study of silicon heterojunction photovoltaic modules exposed to damp heat testing. Microelectron. Eng. 2019, 216, 111081. [CrossRef]

26. Yamaguchi, S.; Ohdaira, K. Degradation behavior of crystalline silicon solar cells in a cell-level potential-induced degradation test. Sol. Energy 2017, 155, 739-744. [CrossRef]

27. Naumann, V.; Hagendorf, C.; Grosser, S.; Werner, M.; Bagdahn, J. Micro Structural Root Cause Analysis of Potential Induced Degradation in c-Si Solar Cells. Energy Procedia 2012, 27, 1-6. [CrossRef] 